\title{
Aksanlı Sinemanın İzleklerinden Hukuk Mücadelesi ve Adalet Arayıșına Keskin Bir Manevra: Paramparça Filmi Üzerine Alımlama Çalıșması
}

\author{
Özlem ÖZGÜR'12 \\ Sevil YILDIZ
}

\begin{abstract}
Öz
Bu araştırma, Fatih Akın'ın 2017 yılında gösterime giren Aksanlı Sinema'nın izleklerini kullansa da bunları anlatının ilerleyen bölümlerinde tersine döndüren; suç, suçluluk, hukuk mücadelesi ve adalet arayışına dair güçlü temsiller sunan Paramparça filmi üzerine gerçekleştirilmiş bir alımlama çalışmasıdır. Bu çalışmanın örneklemi homojen örnekleme yöntemi ile belirlenmiş olup, radyo televizyon sinema alanında lisansüstü eğitimine devam eden 16 katılımcıdan oluşmaktadır. Örneklem grubunu oluşturan katılımcıların Paramparça filmini izlemeleri sağlanmış, ardından katıımcılarla yarı yapılandırılmış görüşmeler gerçekleştirilmiştir. Yarı yapılandırılmış görüşmelerin ses kaydı alınmış ve bu kayıtlar araştırmacılar tarafından bilgisayar ortamında yazıya aktarılarak doküman haline getirilmiştir. Elde edilen dokümanlardaki veriler kodlar, kategoriler ve temalar halinde düzenlenip tümevarımsal bir biçimde organize edilerek bulgulanmıştır.
\end{abstract}

Anahtar Kelimeler: Göçmen, Aksanlı Sinema, Suç, Adalet, Hukuk, Alımlama Çalışmaları.

Atıf (Cite as): Özgür, 0̈. \& Yıldız, S. (2020). Aksanlı Sinemanın İzleklerinden Hukuk Mücadelesi ve Adalet Arayıșına Keskin Bir Manevra: Paramparça Filmi Üzerine Alımlama Çalıșması. Akdeniz Üniversitesi İletișim Fakültesi Dergisi, 34, 399-421. DOl: 10.31123/akil.780445.

1 Dr. Öğr. Üyesi, Selçuk Üniversitesi, İletişim Fakültesi, Radyo Televizyon ve Sinema Bölümü, ozzlemozgur@ gmail.com, ORCID Numarası: 0000-0003-0907-2687.

2 Sorumlu Yazar (Corresponding Author)

3 Prof. Dr., Selçuk Üniversitesi, Iletişim Fakültesi, Radyo Televizyon ve Sinema Bölümü, syildiz@selcuk.edu.tr, ORCID Numarası: 0000-0003-1982-6163. 


\title{
A Sharp Maneuver from the Themes of Accented Cinema to Legal Struggle and Seeking Justice: A Reception Study on the Movie "Aus dem Nichts"
}

\begin{abstract}
This is a reception study on a movie named "In the Fade (Aus dem Nichts)" of the director Fatih Akin, which was released in 2017. Although using the themes of accented cinema, the movie turns those themes round as the narrative proceeds, presenting strong representations crime, guilt, legal struggle and the seek for justice. The gross sample used in this study compose of 16 participants all of whom are postgraduate students majoring in the field of radio-television and cinema. Each participant of the sample group was asked to watch the film In the Fade before the semi-structured interviews were performed with them. Those semi-structured interviews were recorded on a tape, then those recordings were deciphered and typed on the computer by the researcher in order to create documents. The data obtained from the documents were inductively organized by codes, categories and themes in order to be discovered.
\end{abstract}

Keywords: Migrant, Accented Cinema, Crime, Justice, Legal, Reception Studies.

\section{Giriș}

öç, bireysel ve toplumsal düzeyde birçok değişikliğin sebebini ve sonucunu içinde barındırmakla birlikte sosyal yapıyı derinden etkileyen dinamik bir olgudur (Gürsoy, 2019, s.237). Türk toplumu bu olgu ile uluslararası ölçekte II. Dünya Savaşı'ndan sonraki süreçte tanışmıştır. Bu tanışıklık bireysel tercihlerden çok 1960'lı yıllarda baş gösteren ekonomik sıkıntıları ortadan kaldırmak için düşünülen demografik bir alternatif olarak ortaya çıkmıştır (Abadan Unat, 2006, s.1). Böylece hem sanayisinin hızla büyümesi nedeniyle iş gücü sıkıntısı çeken Batı Avrupa'nın sanayileşmiş ülkelerinin sorunu çözülmüş hem de Türkiye'de baş gösteren ekonomik sorunlara kısmen de olsa çözüm üretilmeye çalışılmıştır. Bu süreçte Türklerin yoğun olarak göç ettiği ülkeler arasında Almanya'nın ilk sırada geldiğini söylemek yanlış olmayacaktır.

İlk aşamada Türk işçilerinin geldikleri bu ülkede sürekli kalmayacakları noktasından hareket edilmiş ve (Ünver, 2012, s. 93) ünlü konuk işçi (gasterbeiter) kavramı bu dönemde oluşmuştur (Abadan Unat, 2006, s.58-59). Türk göçmen işçilerin bir kısmı belirli bir süre sonra ülkelerine dönmüş olsalar da bu işçilerin büyük bir çoğunluğu ülkelerine dönmeyi ailevi ve ekonomik nedenlerden dolayı ertelemiştir. Hatta aile birleşimi ve doğumlar nedeniyle nüfusları artmaya devam etmiştir. Bugün Almanya'da Türkiye Cumhuriyeti vatandaşı ve Türk kökenli Alman vatandaşı olan bireylerin sayıları milyonlarla ifade edilmektedir (Ünver, 2012, s.93).

Göç ederek bir topluluktan ayrılıp farklı bir topluluk içine giren insanların yeni sosyal 
ilişkiler kurma zorunluluğu onları çeşitli uyum sorunları yaşamalarına neden olmuştur (Gürsoy, 2019, s.237). Yaşanan bu uyum problemlerine Alman toplumundaki ayrımcı tutum ve davranışlar da eklenince Türk göçmenler toplumsal, ekonomik ve siyasal süreçlerden dışlanmış, bunun da ötesinde yabancı düşmanlığı ve ırkçı şiddetle mücadele etmek zorunda kalmıştır (Ünver, 2014, s.133)

1970'lerde baş gösteren küresel petrol kriziyle beraber Almanya'daki yabancı düşmanlığı belirgin hale gelmiştir (Tauscher ve Bezci, 2016, s.81). Ünver (2012, s.100) Almanya'da Türklere karşı ırkçı şiddetin ilk örneğinin 1979 yılında Hamburg'da bir Türk vatandaşının katledilmesi olayı olduğunu belirtir. 1980'li yıllarda ise Türkleri hedef alan yazıları duvarlarda ve aşırı sağcı gösterilerde görmek sıradanlaşmıştır (Tauscher ve Bezci, 2016, s.81). 1988 yılında Schwandorf'da Türk ve Alman vatandaşlarının yaşamlarını yitirdikleri yeni bir saldırı gerçekleşmiştir. 1990’ı yıllarda ise günlük yaşamda çeşitli biçimlerde yaşanan ırkçı şiddet olayları yeni bir boyut kazanmış (Ünver, 2012,s.100), Berlin Duvarı'nın yıkılıp, SSCB'nin dağıldığı, çift kutuplu dünya düzenin yok olduğu dönemde Doğu Bloku ülkelerinden Batı Avrupa'ya gerçekleşen göç yabancı düşmanlığını körüklemiş ve hızla Neonazi terörizmine dönüşmüştür. (Tauscher ve Bezci, 2016, s.81; Elmas, 2013, s.539). 1992'de Mölln ve 1993'de Solingen kasabalarında Türk göçmenler yine kundaklama sonucu katledilmişlerdir (Ünver, 2012, s.100). Ünver (2012, s.100) bu olaylardaki suçluların genellikle Neonaziler olduğunu, yakalansalar bile cezaların caydırıcı olmadığını ve mahkemelerin suçun ağırlaştırıcı nedenlerini dikkate almadığının altını çizmektedir. Bu süreçte Neonazi terörü sadece Türklere karşı değil farklı etnik gruplardan Alman olmayan göçmenlere karşı da gerçekleştirilmeye devam etmiş, 1996 yılında Almanya'da en büyük kundaklama saldırısı gerçekleşmiştir. Lübeck'teki bir mülteci yurdunu kundaklayan Neonaziler, 6 çocuk toplam 10 kişinin ölümüne sebebiyet vermiştir. Ancak kundaklamayı yapanlar bulunamamıştır. Faillerin bulunamaması, bulunanların da az bir cezaya çarptırılmaları bu gibi kundaklama saldırılarının halen daha devam etmesini sağlayan önemli faktörlerden biri haline gelmiştir. Saldırılar 2000'ler boyunca devam etmiş, son yıllarda ise korkutucu bir boyut almıştır (Tauscher ve Bezci, 2016, s.81). 9 Haziran 2004'te Türk göçmenlerin yoğun olarak yaşadığı Köln şehrinin Keup Caddesi'nde Nasyonel-Sosyalist Yeraltı örgütü üyesi teröristlerin bisiklete bağladıkları çivili bomba düzeneğinin patlatılması sonucu 22 kişi ağır yaralanmıştır (https://www.hurriyet.com.tr/avrupa/keuptaki-turk-esnafinyarasi-hala-kapanmadi erişim tarihi: 22.06.2020). Ayrıca yine bu yıllarda medyada dönerci cinayetleri olarak adlandırılan ve 8 Türk'ün ölümüne neden olan seri cinayetler de gerçekleştirilmiştir. Nasyonel-Sosyalist Yeraltı terör örgütü tarafından işlenen bu cinayetler, soruşturmaların yıllarca aile içi hesaplaşmalar, mafya gibi nedenler etrafında aranması nedeniyle çözülememiş, cinayetlerdeki Neonazi bağlantısının ortaya çıkması için Kasım 2011 tarihini beklemek gerekmiştir (Elmas, 2013, s.539).

Yaşanan olumsuzluklara rağmen, 1990'lı yılların sonlarından başlayarak 2000'li yıllarda yetişen üçüncü kuşak göçmenlerin büyük bir bölümünün birinci ve ikinci kuşağın aksine; daha çok diyaloğa, farklılığa, hoşgörüye açık davranışlar sergilemeye başladığını ve çok kültürlülüğe ilişkin söylemlere ağırlık verdiğini, dolayısıyla kozmopolit bir kimlik geliştirdiklerini söylemek olanaklıdır. Ancak üçüncü kuşağın da kimlik ve aidiyet problemlerinin tam anlamıyla çözüldüğünü söylemek güçtür (Bilgin, 
2007:265). Fransız araştırmacı Nejma Monkachi, göçmenlerin bu süreçte, yeni şeyler üreterek göçmen olma durumlarını kendilerine göre anlamlandırmaları gerekliliğinin altını çizmektedir. Monkachi'ye göre göçmen, köklerine dönmek ile yaşadığı topluma bağlanmak arasında kalmakta ve bu arada kalmışlığı anlamlandırmak adına da bulunduğu toplumda kendisini yeniden üretme ihtiyacı hissetmektedir (2003, s.67). Kendini yeniden üreterek yaşadığı süreci anlamlandırmaya çalışan göçmen birey için sinemanın önemli bir mecra olduğunu söylemek yanlış olmayacaktır.

Sinema göçün farklı boyutlarını bürokrasinin mantığından çekip alarak bunları anlaşılır bir biçimde göstermekte (Ulusay, 2008, s.181); istatistiklerin soğuk rakamlarının ötesinde göçmenlere daha insani bir pencereden bakma fırsatı vermektedir (Yaren, 2008, s.11). Hatta Seesslen'e göre, göçü ve sonuçlarını duyusal olarak sinema dışında bir yolla tanımlamak neredeyse imkansızdır, çünkü sinemanın kendisi göçebe bir vasıtadır (Seesslen'den akt: Ulusay, 2008, s.183) ve diğer sanat dallarından farklı olarak toplumun tüm katmanlarına seslenir, onları aynı seyir zamanı içinde aynı mekânda buluşturarak geniş perdede canlı düşleri izlemesine olanak tanır. Böylece sinema izleyicinin kendisinden ayrılıp bir başkası olmasını mümkün kılar. Olduğu yerde göçebeye dönüşmesine olanak sağlar (Lausten ve Diken, 2010, s.19). Sinema göçebe bir vasıta olmanın yanı sıra göçebe bir endüstridir aynı zamanda. Sinema endüstrisi tarih boyunca, göçmen kimlikli yönetmenler, senaryo yazarları ve kameramanlardan oluşan kozmopolit bir yapı göstermiştir (Kanbur, 2005, s.41). Ayrıca sinema tarihi incelendiğinde perde üzerine yansıtılan hareketli görüntüleri ilgi ile karşılayan ilk izleyiciler arasında göçmenlerin yoğunlukta olduğu görülmektedir. Çünkü sinema hayatın her alanında sanayileşmenin ağır etkilerini deneyimleyen; yabancılaşma, şok ve kayıp hissi yaşayan göçmenler için bu bunaltıcı koşullardan kısa süreli de olsa bir kaçışı vaat etmiş, bu sayede boş zaman geçirme alışkanlıklarından biri haline dönüşmüştür (Kırel, 2010, s.72). Yukarıdaki açıklamalar doğrultusunda denilebilir ki sinemanın hem bir endüstri hem de bir sanat dalı olarak göçebe özellikler taşıması göçmenlerin hikâyelerini anlatma konusunda da onu diğer mecralara kıyasla her zaman üstün kılmıştır.

Türk sineması uzun yıllar boyunca göçün ve göçmenliğin ne olduğu, hangi sonuçlara yol açtığı, göçmenlerin hangi sosyoekonomik ve psikolojik ortamlarda yaşadığı konularını ele almıştır. 1970’li yıllarda Bir Türk'e Gönül Verdim (Halit Refiğ), El Kapısı (Orhan Elmas), Otobüs (Tunç Okan), Almanya Acı Vatan (Şerif Gören) gibi filmler Türk sinemasında dışgöç olgusunu işleyen başarılı yapımlardır (Göktuna, 2005, s.88; Türkoğlu, 2002, s.77). Türkoğlu (2002, s.78) bu filmlerdeki ana temanın kültür, yabancılaşma, çatışma ve endüstri toplumunun insanları sömürmesi olduğunu belirtmektedir. 1980'li yıllardan başlayarak 1990'lı yıllara uzanan süreçte ise dışgöçü konu edinen filmlerden bazıları ise Kara Kafa (Korhan Yurtsever), Ölmez Ağacı (Yusuf Kurçenli), Sahte Cennete Veda (Tevfik Başer), Polizei (Şerif Gören), Alamancının Karısı (Orhan Elmas), Kırk Metre Kare Almanya (Tevifk Başer), Berlin in Berlin (Sinan Çetin) şeklinde sıralanabilir (Türkoğlu, 2002, s.79). Bu filmler Türk işçilerin azınlık statüsüne geçerek varlık göstermeye başladıkları dönemin sosyokültürel boyutlarına ve toplumsal değişmeye odaklanmıştır (Göktuna, 2005, s.88).

1990 ’ı yılların sonu ise genç kuşak yönetmenlerin, bir önceki kuşağın göçmenleri 
ile ilgili karmaşık ve tartışmalı görüşler sunmaya başladıkları, bu yönleriyle de kendilerinden önceki yönetmenlerden belirgin biçimde ayrıldıkları dönemdir (Hake 2002'den akt: Ulusay, 2008, s.193). Çünkü genç kuşak yönetmenler pek çok konuyu farklı konumlandırıp ve birçok sorunun üstesinden gelerek (Nobrega, 2015, s.230-231) kamerayı ellerine almışlardır. Artık Türk işçi göçmenlerinin yönetmen çocukları kültürler arasında kalma halini, kültürel geçmiş olgusunu, gelecekte tekrar göç edebilecek olma durumunu bir yaşam şekli olarak kabul etmiş ve bu durumu filmlerine taşımışlardır (Seesslen'den akt: Ulusay, 2008, s.193). Söz konusu filmler seyirciye evrensel ve transkültürel bir dünya sunmaktadır. Bu durum üçüncü kuşak yönetmenlerin anlatılarının farklı bir biçimde tanımlamasını ve referans edilmesini zorunlu kılmaktadır (Nobrega, 2015, s.230-231). Aysun Bademsoy, Thomas Aslan, Yüksel Yavuz, Neco Çelik ve Fatih Akın ile ilişkilendirilen bu yeni sinema anlayışını (Ulusay, 2008, s.193) Hamid Naficy tarafından geliştirilen Aksanlı Sinema tanımlaması içinde değerlendirmek mümkündür. Bu çalışma Türk kökenli aksanlı yönetmenlerden biri olan Fatih Akın'ın göçmen, suç, suçluluk, hukuk mücadelesi ve adalet arayışı üzerine güçlü temsiller sunan Paramparça filmi üzerine yapılmış bir alımlıma analizidir.

Çalışmanın bulgularına geçmeden önce, Aksanlı Sinema, Fatih Akın'ın sinemasal anlayışı, Paramparça filminin Aksanlı Sinema'nın bir yandan izleklerini kullanırken diğer yandan neden hukuk mücadelesi ve adalet arayışının filmi olduğu açıklanmış ve son olarak da çalışmanın yöntemini oluşturan aktif izleyiciyi merkeze alan alımlama çalışmalarının gelişim sürecine değinilmiştir.

\section{Hamid Naficy'nin Aksanlı Sinema Yaklașımı}

Hamid Naficy Aksanlı Sinema kavramlaştırmasını Batı'da yaşayan diasporik kimlikli sinemacıların ürettikleri filmleri adlandırmak için kullanılır. Naficy yerleşik ama evrensel olarak tanımladığı aksanlı sinemacıları iki grupta toplar. Birinci gruptaki sinemacılar, 1960’ı yıllardan başlayarak sömürge sonrası bağımsızlık hareketleri ve Doğu Avrupa'ya Sovyet müdahaleleri neticesindeki göç sonucu ortaya çıkmıştır. İkinci gruptaki sinemacılar ise 1980'li yıllardan başlayıp 1990'lı yıllar boyunca devam eden bir dizi toplumsal dönüşüm sonucu filmler üretmeye başlamıştır. Sosyalist Blok'un dağılması ve küresel dünya düzenin ortaya çıkması, ulusal devletlerin parçalanması, dinsel ve etnik kökenli savaşların geri dönüşü, $A B D$ ve Avrupa'nın yeni göç politikaları ile Batı dışı toplumun üyeleri tarafından gerçekleştirilen göçler ve teknolojik alandaki gelişmeler bu yeni sinemacı kuşağının oluşmasını sağlamıştır (2001, s.10-11).

Aksanlı Sinema'daki, aksanfilmlerdekikarakterlerinkonuşmalarındançokyönetmenlerin üsluplarını şekillendiren yerinden edilmişlik durumundan kaynaklanmaktadır (Suner, 2006, s.258-260). Dolayısıyla Aksanlı Sinema'nın yaratıcıları filmlerinde kendi deneyimlerini ya da kendi deneyimlerine benzer deneyimleri sorgular. Yönetmenlerine ait otobiyografik izler taşıyan konulara odaklanan aksanlı filmler parmak izi gibi tek ve eşsizdir (Kırel, 2004, s.39).

Kimlik, aidiyet ve yurtsuzlaşma konuları ile ilgilenen Aksanlı Sinema'da, her hikaye hem bireyin özel bir hikayesi hem de diasporanın sosyal ve kamusal bir hikayesidir (Naficy, 
2001, s.31). Bu hikâyeler perdeye taşınırken çok dillilik dikkat çeker. Birden fazla dilin konuşulduğu filmlerde karakterler bunu son derece normal bir biçimde günlük hayatın akışı içinde gerçekleştirir.

Aksanlı filmlerde en fazla işlenen konu ise yolculuk temasıdır. Naficy'e göre (2001, s.222) karakterin bir arayış içinde başladığı yolculuğu; keşif, yeni bir göç veya dönüşle sonuçlanabilir ya da sürgüne dönüşebilir. İçe doğru yapılan yolculuklarda ise görüntü ve ses kayıtları, fotoğraflar ya da mektuplar ile harekete geçirilen bellek anlatının önemli bir parçası haline gelir.

Suner (2006, s.261-262) Aksanlı Sinema'da karakterin yolculuğunun yalnızca mekanın değil aynı zamanda kimliğin de sınırlarının sorgulanması anlamına geldiğini belirtir. Bu filmlerde kimliğin toplumsal olarak inşa edilmiş ve kurgulanmış olma durumu farklı sinemasal stratejilerle ortaya konmaktadır.

\section{Türk Kökenli Aksanlı Sinemacılar ve Fatih AKIN}

1990'lı yıllardan itibaren Alman Sineması'nda yapımlarıyla dikkat çeken Aksanlı Sinema'nın Türk kökenli temsilcileri arasında Thomas Aslan, Yüksel Yavuz, Neco Çelik ve Fatih Akın gibi isimler öne çıkmaktadır (Ulusay, 2008, s.193). Genelde bu yönetmenler göçmen kökenlerinin farkında olarak zamanla yerleşik hale geldikleri ev sahibi toplum içerisinde yer edinmişlerdir. Söz konusu yönetmenlerin filmlerinde artık sömürülmüş konuk işçiler, acı çeken eşler ve baskılanan genç kızların hikayeleri yoktur. Bu yönetmenler filmlerinde bir önceki nesille ya da azınlık konumlarına açık olan göçmen, mülteci gruplarla yaşanan çatışma deneyimlerine ilişkin kendilerinden emin yanıtlar sunar (Hake ve Mennel, 2012, s.6-7). Çoğunlukla gençlerin dünyalarının konu edildiği, Almanca ve Türkçe'nin konuşulduğu kimi zaman da İngilizce'nin üçüncü bir dil olarak anlatıya dahil olduğu bu filmlerde yol ve yolculuk teması ön plandadır. Karakterler her an yeni bir yolculuğa çıkabilir ya da yeni bir maceraya atılabilirler (Ulusay, 2008, s.196).

Thomas Aslan, Berlin üçlemesi olarak bilinen Kardeşler, Satıcı ve Güzel Bir Gün filmlerinde Türk kökenli göçmenlerin hayatlarına değinirken çeşitli suçlara bulaşan gençlerin sorunlarına farklı bir bakış geliştirmeye çalışır. Benzer şekilde Yüksel Yavuz'da Nisan Çocukları ve Küçük Özgürlük filmlerinde göçmen aileler, kuşak çatışması, uyuşturucu satışı ve suç üzerinden anlatısını geliştirir. Neco Çelik ise Şehir Gerillaları filminde 1990'ı yıllarda Türk ve Alman gençleri arasında hızla yaygınlaşan küresel boyutta bir direniş kültürünü ele alır (Ulusay, 2008:196-207), suç, şiddet ve uyuşturucunun yerine Grafitti ve Hiphop kültürünü yerleştirir (Yaren, 2008, s.131). Neco Çelik'in bu filmi hariç yukarıda adı geçen filmlerin tamamında yerleşik göçmenlerin getto merkezli anlatılarda kurban ya da suçlu stereotipleriyle ama her durumda sorun olarak sunulduğu görülmektedir (Yaren, 2008, s.138). Ancak Fatih Akın ülkeler ve şehirlerarasında gezinen kamerası ile bu yönetmenlerden farklı olarak ilk filmi olan Kısa ve Acısız'dan itibaren Temmuzda, Solino, Duvara Karşı ve Yaşamın Kıyısında filmlerinde göçmen temsillerini suçlu ve sorun kaynağı olmanın ötesine taşır (Ulusay, 2008, s.208). Bu filmlerde baskın dil Almanca'ya farklı diller eklenmekte, kahramanlar 
hem ruhsal hem de gerçek anlamda yolculuklara çıkmakta, yolculukların sonunda dönüşüm geçirmekte böylece filmin başladığı noktadan farklı bir yere varmaktadır. Yönetmenin filmlerinde göçmenlik alt metin olarak bulunurken anlatı yeni temalarla farklı bir boyuta taşınır. Asıl önemli olan insan ilişkileri ve diyalogtur. Bu yönüyle Fatih Akın Aksanlı Sinema'da ayrı bir yere sahiptir (Deliormanlı, 2011, s.296).

Fatih Akın 2017 yılında gösterime giren 75. Altın Küre Ödülleriınden Yabancı Dilde En İyi Film ödülü almış filmi Paramparça (Aus dem Nichts) ile Neonazi'lerin yerleşik göçmenlere karşı işledikleri nefret suçlarına dikkat çeker. Yönetmen bu filmin çekimine karar verme gerekçesini yaşadığı topluma karşı sorumluluk hissi olarak açıklar. Ayrıca Akın, Almanya'daki yabancı düşmanlığını çok küçük yaşlarda fark ettiğini, bunun kendisinde travmatik izler bıraktığını ve bizzat içinde yaşadığı hesaplaşmaların diğer filmlerinde olduğu gibi bu filmine de konu olduğunu belirtir (http://www.hurriyet.com. tr/yazarlar/ayse-arman/bu-filmi-yapma-dediler.erişim tarihi: 19.01.2020).

Yönetmen diğer filmlerinde olduğu gibi Paramparça filminde de Aksanlı Sinema'nın izleklerini kullanır. Filmde hakim dil Almanca olsa da Türkçe ve Íngilizce de diyaloglara dahil olur. Göçmen karakter Nuri Şekerci Türkiye'den Almanya'ya göç etmiş bir ailenin oğludur. Gençlik yıllarında uyuşturucu satıcılığı yapmış olsa da sonrasında Katja ile evlenmiş kendine düzgün bir hayat kurmuştur. Fatih Akın diğer Türk kökenli aksanlı sinemacılar gibi bu filmde de göçmen ve suç ilişkisini kullanmıştır. Ancak filmsel anlatı içerisinde karakterine bir şans vermiş ve dönüşüm geçirmesine olanak tanımıştır. Hayatını yeniden kuran Nuri'nin suçtan uzak yaşamı çok uzun sürmez, işyerinin önüne bırakılan bisiklete bağlı çivili bombanın patlaması sonucu oğlu ile birlikte hayatını kaybeder. Bu sahne, "2004 yılında Nasyonel-Sosyalist Yeraltı Örgütü'nün Almanya'nın Köln şehrinin Keups Caddesi'nde bisiklete bağlı çivili bombanın patlatılması ile gerçekleştirdiği terör eylemine atıfta bulunmaktadır (Spiegel Online, 2017'den akt: Kültür, 2017, s.13)".

Nuri ve Rocco'nun bombalı saldırı sonucu ölümlerinin ardından Nuri'nin ailesi memleketlerine yani Türkiye'ye döner. Giderken oğullarının ve torunlarının cenazelerini götürmek isterler. Film bu yönüyle Aksanlı Sinema'daki yolculuk teması ile paralellik gösterir. Ancak Akın sadece Nuri'nin anne ve babasının yolculuğu ile yola çıkma durumunu sonlandırmaz. Aksanlı Sinema'nın yolculuk temasını tersine çevirir. Göçmen olmayan Alman toplumunun bir üyesi olan Katja yargılama sürecinin adaleti sağlamadığına olan inancı nedeniyle kendi adaletini sağlamak adına yola çıkar. Söz konusu yolculuk bir yere ulaşıp varlık sürdürmek ve yerleşik hale gelme amacıyla yapılan bir yolculuk değildir. Aslında Katja kendi adaletini aramak için çıktığı yolculuk öncesinde hukuki yollardan girişimde bulunmuş, ancak beklediği sonucu alamamıştır. Katja'nın adalet arayışı, yani soruşturmanın başlatılması ve yargılama süreci filmsel anlatı içerisinde ayrıntıları ile işıenmiştir. Dolayısıyla Paramparça her ne kadar Aksanlı Sinema'nın izleklerini kullansa da anlatının ilerleyen aşamalarında maruz kalınan ırkçı şiddet ve haksızlık karşısında bireylerin hukuk ve adaletten beklentilerini temsiller yoluyla izleyicisine sunmaktadır. Bu yönüyle Paramparça'yı hukuk mücadelesi ve adalet arayışını merkeze alan bir film olarak da değerlendirmek mümkündür. 


\section{Hukuk Mücadelesinin ve Adalet Arayıșının Filmi Olarak Paramparça}

Paramparça filmindeki hukuk mücadelesi ve adalet arayışına değinmeden önce, hukuk ve sinema ilişkisini açıklamak yerinde olacaktır. Kamir'e (2006, s.2) göre hem hukuk hem de film; bireysel ve toplumsal kimlik, bellek, cinsiyet rolleri, adalet ve gerçek gibi kavramların inşasında baskın öğeler olup her ikisi de kolektif umutların, hayallerin, inançların, endişelerin ve hayal kırıklıklarının halka açık bir şekilde değerlendirildiği ve sahnelendiği önemli sosyokültürel alanlardır. Ancak sinemanın hukuka göre avantajı kendine özgü anlatım teknikleriyle olayları izleyicisine bütüncül boyutta sunabilmesidir. Ayrıca filmler sadece saf hukuki bir sorunu ya da işlenen suçu aktarmaz, aynı zamanda o sorunun bireysel ve toplumsal sonuçlarını, psikolojik etkilerini de gösterir. Bu nedenle hukukun her alanı sinema filmlerine konu olabilir, her kavram hukuksal yönü ile sinemasal anlatılar dahilinde tartışılabilir (Karacaoğlu,2014, s.2), büyük ölçekli yasal telkinler gerçekleştirebilir; yani yasal normların mantığı ve yapıları güçlendirilebilir, izleyiciler yargının aktif bir şekilde icra edilmesi konusunda eğitebilirler (Kamir, 2006, s.2). Böylece sosyal hayattaki ilişki biçimlerine filmler aracılığıyla yön verilebilir (Elkins, 2007, s.752).

Hukuki süreçleri merkeze alan filmlerde hukuk, izleyiciye, bazen adil olarak gösterilir, bazen de hukuki olarak alınan kararlar adaletsizlikle özdeşleştirilir (Saygılı, 2014, s.70- 71). Ancak hukuki süreçleri konu edinen yargılama odaklı filmlerdeki mahkeme sahnelerinin doğru sunumunun gerçekleştirildiğinde, izleyicide tarafların çıkarına uygun olan her şeyin adalet olmadığı algısının ve kültürünün oluşmasına da hizmet edebilir (Balcı, 2014, s.351-352).

Paramparça filminde mahkeme salonu gerçekçi bir biçimde tasarlanmıştır. Filmsel anlatı içerisinde yargılama süreci 30 dakika sürmektedir. Bu süreçte Katja ve avukatı Danilo'nun duygu durumları, üzüntüleri ve süreci değiştirebilmek adına verdikleri mücadele sık sık yakın çekimlerle desteklenirken, sanıkların avukatının duygulardan arındırılmış, hedefe kitlenmiş hali de yakın çekimlerle perdeye yansıtılır. Beraat kararını duyuncaya kadar tepkisiz bir biçimde önüne bakan sanıklar ise kararın açıklanmasından hemen sonra sevinçle birbirlerine sarılırlar ve sadece bu tepkileri yakın çekimler aracılığı ile gösterilir. Bu süreçte kamera tarafları ve mahkeme salonunu çeşitli açılardan göstermeye, bulunulan yeri hatırlatmaya devam eder. Böylece taraflar arasındaki karşıt durum izleyicinin de sürece dâhil olmasıyla belirgin hale gelir.

\section{Yöntem Üzerine}

Sinema izleyicisi her dönem sinema teorisyenleri tarafından ilgi ile karşılanmış, neredeyse tüm sinema teorileri izleyicilikle ilgili yaklaşımları da beraberinde getirmiştir (Stam, 2014, s.238).

Hugo Münsterberg 1916 yılında izleyiciyi konu edinen ilk çalışmayı gerçekleştirmiştir. $\mathrm{Bu}$ süreçte film izleyerek izleyiciye ne olur sorusuna yoğunlaşarak erken seyir deneyimini ortaya koymuştur (Akbulut, 2014, s.2). 1920'lerde Antropolog W. Hudson da, Batılı kültürlerle az da olsa ilişki kurmuş olan kırsal kesimde yaşayan Afrikalıların 
iki boyutlu görüntülerdeki derinliği Avrupalılar gibi anlayamadığını saptamıştır. Bu deneyle insanların görsel bir imgeyi teşhis edebildiği ancak en basit görsel imgelerin bile farklı kültürlerce farklı biçimde yorumlandığı saptanmıştır (Monaco, 2002, s.151). Bu nedenle insanların görüntüyü okumayı öğrenmesi gerekmektedir. Erdoğan (1993, s.47) bu durumun sinemanın kendine özgü bir dil yaratma potansiyelinden kaynaklandığını belirtmektedir. İnsanların fotoğrafik görüntüleri sinema diline yabancı olmaları nedeniyle kavrayamadıklarını da eklemektedir. Deneye katılanlar görüntüyü izlemiş ancak okuyamamıştır.

1920'li yıllarda ise sinemanın çocuk izleyicileri ile ilgili ilk kapsamlı çalışmalardan biri Payne Fund Vakfı'nın desteği ile gerçekleştirilmiştir. Bu dönemde; aşk, suç ve seks gibi içeriklere sahip filmlerin çocuk izleyiciler üzerindeki etkilerini konu alan 13 ayrı araştırma yapılmış ve farklı başlıklarla yayınlanmıştır (Özçetin, 2018, s.94).

Seyirci araştırmalarında Laura Mulvey'in Klasik Hollywood sineması üzerine yapmış olduğu çalışma da oldukça önemlidir (Akbulut, 2014, s.2). Mulvey kültleşmiş makalesi Görsel Haz ve Anlatı Sineması (1997) sayesinde izleyiciliğin cinsiyetçi olduğunu açıkça ortaya koymuştur.

Sinema ve seyirciye odaklanan bu erken çalışmalar zamanla filmlerin büyüsüne kapılarakazalmış ancak 1980'lerde yeniden önemli bulunmaya başlanarak, çalışmaların odağına metin değil seyirci konulmuştur (Sarı Karabağ, 2012, s.3). Artık seyirci güçlü etkin bir özne olarak kabul edilmekte (Stam, 2014, s.239-240) ve filmin bu özneler için ne ifade ettiğinin ortaya konulması amaçlanmaktadır. Çünkü alımlama çalışmaları anlamın seyirci ile girdiği etkileşim ile üretildiğini; bir filmin içerdiği anlamların daha çok izleme bağlamında şekillendiğini, zaman içinde izleyicinin değişmesi gibi anlamın da değişebileceğini öğretir (Lehman ve Luhr, 2008, s.172-173). Hatta R. S. Allen (1990) Screen dergisinde yayınladığı makalesinde metin temelli sinema çalışmaları geleneğine karşı çıkmaktadır. Allen'e göre (1990, s.348) bir araştırmacı ciddi bir sinema tarihi yazmak istiyorsa izleyiciyi dışarıda bırakma düşüncesinin yakınından bile geçmemelidir.

Bu dönemde sinema seyircisi üzerine yapılan bir diğer araştırma da J. Stacey'e aittir. Stacey, çalışan kesimden ve 60 yaş üstü olan bir grup İngiliz kadınının sinemaya gitme gerekçelerini kaçış, özdeşleşme ve tüketicilik başlıkları altında bulgulamıştır. Böylece sinemanın sosyal hayat ve gündelik yaşam pratikleri içindeki yeri saptanmıştır (Stacey, 1994'den akt: Storey, 2000, s.80-88).

Benzer şekilde Hansen de gerçekleştirdiği çalışmasında sinemanın kadınların birer tüketici olarak ailelerinden farklı bir topluluğa katılmak üzere tek başlarına gidebilecekleri bir yer olduğunu dolayısıyla sinemanın kadın sinemaseverler için, medeni durum, yaş veya geçmişe bakılmaksızın sosyal bir alanı ifade ettiğini saptamıştır (1991, s.118).

Alımlama çalışmalarında günümüzde en yaygın olarak benimsenen yaklaşım Janet Staiger tarafından geliştirilen Tarihsel Materyalist Yaklaşımdır (2000, 2005). Anlamın metin, okuyucu ve kendisini çevreleyen tarihi ve toplumsal güçler arasındaki etkileşimden kaynaklandığını öne süren Staiger (2000, s.1), izleyicilerin filmsel ve sinematik deneyimleri incelenirken bağlamsal faktörlerin göz önünde bulundurulmasının 
gerekliliğine değinmekte, metin, bağlam ve aktif izleyici arasındaki etkileşimin altını çizmektedir.

Barbara Klinger'in sinematik alımlamaya ilişkin yaklaşımı Staiger'in yaklaşımı ile paralellik göstermektedir. Klinger, sinema uygulamalarıyla sosyal ve tarihsel bağlamlar arasındaki derin etkileşimli ilişkinin kabul edilmesini önermektedir. Alımlama çalışmalarında, filmin sosyal anlamlarının izleyici tarafından nasıl kabul edildiğini anlamak için bu bağlamsal öğeleri incelemenin önemli olduğunu ileri sürmektedir (1997, s.113-114). Klinger için (1997, s.114), izleyici, bir filmin etrafındaki tarihsel anlamların akışıyla ilişkili olarak sabit bir yerde bulunmaz ve bir merkeze, merkezin dışına veya başka bir yere yerleştirilemez. Biçimlendirilmiş bir izleyici elde etmeden ziyade filmlerin izleyicileri nasıl bir konum almaya davet ettikleri betimlenmelidir.

\section{Veri Toplama Süreci}

Paramparça filminde göçmenliğin, suçun, hukuk mücadelesinin ve adalet arayışının katıımcılar tarafından nasıl alımlandığının araştırıldığı bu çalışmanın örneklemi homojen yani benzeşik örnekleme yöntemi ile belirlenmiştir. "Olabildiğince benzer özelliklere sahip olan (Yıldırım ve Şimşek 2008:109)", radyo televizyon ve sinema alanında lisansüstü eğitimine devam eden 7 kadın, 9 erkek toplam 16 öğrenci örneklem grubunu oluşturmuştur. Katılımcılara öncelikle Paramparça filmi izlettirilmiştir. Ardından katılımcılarla yarı yapılandırılmış görüşmeler gerçekleştirilmiştir. Veri toplama sürecinde yarı yapılandırılmış görüşmelerin tercih edilmesinin nedeni ise araştırmacıların "her ne kadar veri toplama sürecine ilişkin bir planı geliştirmiş olsa da katılımcılardan gelen yanıtlara göre yeni sorular da ekleyebilmesi (Güler, Hacıoğlu ve Taşgın, 2013, s.113)" ve katılımcıları çok sınırlamadan konuşmalarını sağlayarak, dünyayı anlamlandırdıkları haliyle anlatma özgürlüğü tanımasıdır (Noaks ve Wincup, 2004, s.80). Yarı yapılandırılmış görüşmelerde araştırmacıların katıımcılara yönelttiği sorular aşağıdaki gibidir:

Suç filmleri tercih ettiğiniz türler arasında mı? Neden tercih ediyorsunuz veya etmiyorsunuz?

- Filmde sizce hangi suç türleri mevcut?

- Filmde suçlu profilini nasıl tanımlarsınız?

- Filmdeki en dokunaklı sahne sizin için hangisiydi?

- Saldırıya kurban giden kişilerin neden hedeflendiğini düşünüyorsunuz?

- Filmde önyargılı davranan ötekileştiren taraflar var mı?

- Filmsel anlatı içerisinde damgalama var mı?

- Filmde kadın karakterin adaleti arama sürecinde benimsediği yol hakkında ne düşünüyorsunuz?

- Kolluk kuvvetlerinin soruşturma sürecini başlatırken takip ettikleri yol hakkında ne düşünüyorsunuz?

- Filmde hangi karakter ile özdeşlik kurdunuz ve ne hissetiniz?

- Mahkeme heyetinin yargılama sürecini yönetimi konusunda dikkatinizi çeken ne oldu?

- Ebeveynlerin tutumu hakkında ne düşünüyorsunuz? 
- Gündelik hayat ve suçun bu kadar içiçe geçmesi hakkında ne düşünüyorsunuz?

- Sizce adalet nedir?

Katılımıcılarla gerçekleştirilen yarı yapılandırılmış görüşmelerin ses kaydı alınmış ve bu kayıtlar araştırmacılar tarafından bilgisayar ortamında yazıya aktarılarak doküman haline getirilmiştir. Ses kayıtları doküman haline getirilirken katılımcıların gerçek isimleri kullanılmamış her birine bir numara verilmiştir (K1, K2 şeklinde).

Doküman haline getirilen veriler araştırmacılar tarafından kodlanarak yani "etiketlenerek (Miles ve Huberman, 2016: 56)" veri çözümleme süreci başlatılmış ve kodlama işlemine çözümleme süresince devam edilmiştir (Punch (2011, s.195). Elde edilen kodlar tümevarımsal bir şekilde organize edilerek kategorilere ve temalara ulaşılmıştır. Ayrıca araştırmacılar elde edilen temaları sürekli olarak geri dönüp kodlarla karşılaştırarak kontrol etmiş̧ir (Creswell, 2013, s.45; Glesne 2012, s.251).

\section{Bulgular ve Yorum}

\subsection{Suç Filmlerinin Katılımcılar Tarafından Tercih Edilip Edilmeme Durumu}

Katılımcılara suç filmlerini tercih edip etmedikleri sorulduğunda 3 katılımcı bu türe dair özel bir tercihleri olmadığını ancak izleyebileceklerini belirtmiştir. Suç filmlerini tercih etmeyen 3 katılımcı ise Paramparça filmde olduğu gibi adalet tecelli etmezse bunun onlar için oldukça rahatsızlık verici olduğunu bu nedenle suç türüne biraz mesafeli yaklaştıklarını dile getirmiştir. Bir başka katılımcı suç odaklı filmleri sevdiğini, bazen hayal kırıklığına uğrasa da adaletin sağlanacağına olan inancını yitirmediği için bu türe olan ilgisini de kaybetmediğinin altını çizmiştir. 9 katılımcı suç filmlerini tercih ettiklerini belirtmiş̧lerdir. Bu katılımcılar hayatın monotonluğundan kısa süreli de olsa suç filmlerinin içerdiği aksiyon sayesinde kurtulduklarını dile getirmişlerdir. Bu durum araştırmacılar tarafından "kaçışçı hazların (Kırel, 2010, s.20)" tercih edilme durumunu etkilemesi olarak değerlendirilmiştir.

\subsection{Paramparça Filminin Geneline Hakim Olan Suç Türü: Nefret Suçu}

Katılımcıların tamamı Paramparça filmindeki en belirgin suç türünün nefret suçu olduğu konusunda hemfikirdir. K8 saldırıya kurban gidenlerin hedeflenme gerekçelerini "ırkçı kör şiddet bu, tahammülsüzlük, hiçbir rasyonel tarafı olmayan zenofobi” şeklinde açıklar. Hatta katılımcılar ırkçılık temelinde gerçekleştirilen nefret suçunun filmin geneline hakim olduğunu diğer suçların oluşmasında da bir tetikleyici rol üstlendiğini belirtmektedir. Çünkü Katja, eşi ve çocuğu öldürüldükten sonra uyuşturucu kullanmış ve kendi adaletini sağlamak adına bombalı saldırıyı düzenlemiştir.

\subsection{Filmdeki Baskın Suçlu Profili: Soğukkanlı Motive Olmuș Suçlular}

Katılımcıların tamamı Möller Çifti'ni soğukkanlı ve ideolojik anlamda motive olmuş 
suçlular olarak tanımlamışlardır. Katılımcılar bu çifti her ne kadar soğukkanlı görse de suçu işlerken çok da bilinçli bir şekilde hareket etmedikleri dolayısıyla onların da kurban olduğunu perde arkasından yönlendirildikleri üzerinde durdurmuşlardır. Bu nedenle de filmi izlerken bu çift için de üzüldüklerini dile getirmişler ancak masum insanların canına kast etmenin de affedilir bir yanının olmadığını da belirtmişlerdir.

\subsection{Asıl Suçlu Adaleti Sağlayamayan Hukuk Sistemi}

Katılımcılar adaleti sağlayamayan hukuk sisteminin ve bu sistemin temsilcilerinin yani hakim, savcı, avukat gibi yetkililerin asıl suçlu olduğunu belirtmişlerdir. K3, K7 ve K16'nın bu konudaki görüşleri diğer katılımcıların görüşlerini kapsar niteliktedir. K3 ve K7 "doğru kararı vermeyen yetkililerin asıl suçlular olduklarını" belirtmiştir. Benzer şekilde K16 da "suçlu adaleti tanzim edemeyen kurum ve yetkili kişiler. Bu çift suçunu gayet iyi biliyor ama aklanacaklarını da biliyorlar" şeklinde kurumların ve yetkili kişilerin bu süreçte asıl suçlular olduğunu işaret etmiştir.

\subsection{Filmin En Dokunaklı Sahneleri}

Adli tıp raporunun okunduğu sahne 9 katılımcı için en dokunaklı sahne olarak öne çıkmaktadır. Bu katılımcılar kendilerinin de çocuk sahibi olduğunu, bu sahneyi çocuklarını ve ailelerini düşünerek izledikleri için çok zorlandıklarını dile getirmişlerdir. 7 katılımcı için filmin en dokunaklı sahnesi olarak Katja'nın tekrardan adet görmeye başladığı sahnedir. Katılımcılar bu sahneyi son derece gerçekçi ve doğal bulmuştur. K3 bu sahneyi "çok gerçek bir sahne artık yaşamayacağını anladı, karar verdi" şeklinde ifade etmiştir. K8 "Katja katil olamayacağını anladı ve o noktada tekrar biyolojik döngüsü başladı" derken, K11 "hayatından vazgeçti, o sahnede ben anladım kendini de işin içine katacak, ama bir yandan da hayat devam ediyor. Kadın normal döngüsüne geri dönüyor. Bu bana çok dokundu" şeklinde açıklarken, K4 "oğlunu ve kocasını kaybettikten sonra resmen kendini beklemeye aldı, kitlendi, ama karar verdi ve adet görmeye başladı" diyerek Katja'nın karar vermesi ile adet görmeye başlamasına dikkat çeker. K16'da benzer şekilde "çifti öldürdükten sonra bu vicdan yükü ile yaşayamayacaktı. Vicdanı devreye girdikten sonra adet gördü, çünkü artık ne yapacağını biliyordu. Demek ki vicdanımız devreye girdikten sonra damarlarımızda kan akmaya devam ediyor" şeklinde değerlendirmiştir.

\subsection{Suça Seyirci Kalanlar da Suçun Sorumluluğunu Tașır}

Katılımcıların tamamı Jurgen Möller’i oldukça samimi bulmuş ancak oğlunun suçunu biliyor olmasına rağmen vaktinde haber vermemesini de doğru karşılamamışlardır. Jurgen Möller'in bu durumunu, hukuki açıdan doğru olanı yapmak ile evladı arasında seçim yapmanın zorluğundan kaynaklandığını düşüncesi ile gerekçelendirmektedirler. Hatta K8 Jurgen Möller'in vücudunun tamamını Katja'ya dönerek özür dilemesinin 
oldukça önemli olduğunu ve en samimi karakterin de Jurgen Möller olduğunu belirtmekle birlikte "sonuçta insan evladından vazgeçemiyor, suçlu bile olsa" diyerek Jurgen Möller'in de suça bir şekilde sessiz kalarak dahil olduğunu kabul etmekte ve bu durumu baba olmakla açıklamaktadır. Benzer şekilde K3, K5, K2 ve K13 Jurgen Möller'in naif ve merhamatli bir tavır sergilediğini ancak daha önce de benzer suçları işleyen sabıkalı oğlunun durumunu biliyor olmasına rağmen ihbar için bu kadar geç kalması nedeniyle onun da en az Edda ve Andre kadar suçlu olduğunu düşünmektedir. Katılımcıların bu tutumu Jaspers'in (2015) Nazi döneminde bir eyleme katılmamış olanlarla ilgili olarak yaptığı saptama ile ilişkilendirilmesi yanlış olmayacaktır. Jaspers (2015, s.98-101) Nazi döneminde ırkçı eylemlere katılmamış işbirliği içinde olmamış ancak tepki de göstermemiş, Nazi düzenine seyirci kalmış olanların da sorumluluk taşıdığını belirtir. Bu suça seyirci olanların da suçu ahlaki olarak paylaştığının altını çizer.

Ayrıca K12 de Jurgen Möller ile ilgili olarak "kendi çocuğunu korumaya çalışırken vaktinde ihbar etmedi, vahşete neden oldu, filmin sonunda da Katja'nın yerine geçti” şeklindedir. Katılımcı terör olayları aracılığı ile gerçekleştirilen şiddet eylemlerinde yaşanan kaybın arkasından acının ve tutulan yasın değişmediğini sadece tarafların değiştiğine işaret etmiştir.

\subsection{Göçcmenin Yolculuklardan Kurtulamayan Cansız Bedeni}

Katılımcılardan K7 ve K5 Nuri'nin ailesinin cenazeyi memleketlerine götürme isteklerini özellikle Katja bu kadar acı çekerken bunu teklif etmelerini doğru bulmamaktadır. Katılımcılardan K1, K3, K6 ve K16 Nuri Şekerci'nin ailesinin oğullarının ve torunlarının cenazesini memlekete yani Türkiye'ye götürmek istemelerini anlayışla karşılamakta ve Türk geleneklerinde cenazenin memlekete getirilmesinin olduğunu belirtmektedirler. Dolayısıyla göçmenin bedeni cansız bile olsa yolculuklardan kurtulamamaktadır. Ulusay'ın bu noktadaki saptaması oldukça önemlidir. Ulusay (2012, s.119-120) göçmenin bedeninin en görünen ve en korumasız bedenlerden biri olduğunu ve sınavlara tabi tutulduğunu belirtmektedir. Göçmenin cansız bedeni de bu sınavlardan nasibini alır. Göçmenin cenazesi kendi ülkesine defnedilmek üzere yeni bir yolculuğa başlayabilir.

\subsection{Hoșgörüsüzlüğüun ve Tahammülsüzlüğün Sınırlarında Gezen Ebeveynler}

K8'in "herkes paramparça, herkes bir diğerinin ötekisi o kadar yıl aynı ülkede yaşıyorlar ama iletişim kuramıyorlar, kültürlerini öğrenmiyorlar, birbirlerini anlama yoluna gitmiyorlar" şeklinde gerçekleştirdiği okumada her iki ebeveyni ve aileyi değerlendirmesi tüm katılımcıların düşüncelerinin özeti gibidir. Dolayısıyla katılımcılar aynı toplumsal yapı içerisinde biri ev sahibi toplumun öbürü de göçmen diasporasının bir parçası olan ebeveynlerin çocuklarının gerçekleştirdiği evlilik sonucu mecburen doğan ilişkilerinde hoşgörüyü ve tahammülü göz ardı ettiklerini, birbirlerini tanımak, kültürel değerlerini öğrenmek yerine ötekileştirme yoluna gittikleri konusunda hemfikirdir. 


\subsection{Filmde İzleyicinin Özdeșlik Kurduğu Karakterler}

Katılımcıların özdeşlik kurduğu karakterler arasında Katja, Katja'nın avukatı Danilo ve soruşturmayı yürüten komiser bulunmaktadır. 9 katılımcı Katja ile, 4 katılımcı Danilo ile, 3 katılımcı komiser ile, özdeşlik kurduğunu belirtmiştir. Katja ile özdeşlik kuran karakterler bu süreçte kendi ailelerini düşündüklerini belirtirken, Avukat Danilo ile özdeşlik kuranlar Danilo'nun adaletsizlikle hukuk yolu ile mücadele etmesinden, hiç vazgeçmemesinden ve suçluları ötekileştirmek yerine onları topluma kazandırmak için uğraşmasından etkilendiklerini belirtmişlerdir. Soruşturmayı yürüten komiser ile özdeşlik kuran katılımcılar ise işini yaparken hem nazik hem de profesyonel olması ve soğukkanlı davranması şeklinde özdeşlik kurma gerekçelerini dile getirmişlerdir. $\mathrm{Bu}$ açıklamalar doğrultusunda katılımcıların özdeşlik kurmalarında işlerini layıkıyla yapmanın, önyargılı hareket etmemenin ve aile sevgisinin etkili olduğunu söylemek olanaklıdır.

\subsection{0. Önyargılı Davranan, Ötekileștiren ve Damgalayan Karakterler}

14 katılımcı Nuri Şekerci'nin göçmen bir suçlu olarak yeni bir hayat kurabileceğine dair güçlü bir önyargının var olduğunu, bu nedenle de ötekileştirilip damgalandığı görüşünde hemfikirdir. Bu katılımcılar Katja'nın da Nuri ile evli olmasının ötekileştirilmek için geçerli bir sebep olduğunu da belirtmektedir. Hatta K3 çiftin Yunanistan'da onları saklayan arkadaşları tarafından uyarıldıktan sonra Andre Möller'in "Türk orospusu" diyerek Katja'ya hakaret etmesine dikkat çeker. Alman olduğunu bildiği halde Türk ile evli olduğu için Katja'yı ötekileştirdiğini ve damgaladığını dile getirir.

K8 “Neonaziler için Katja ve eşi öteki iken, Katja’nın annesi için Nuri ve ailesi öteki olduğunu, Türkler için de Almanların öteki olduğunu hatta Katja'nın avukatı ile Möller çiftinin avukatının birbirlerinin ötekisi olduğunu" belirtmekte dolayısıyla filmde tek bir tarafın öteki olmadığını herkesin birbirinin ötekisi olduğunu düşünmektedir.

Ayrıca K16, "filmde öteki kişi değil de kavram bence, ötekileştirilen adalet" diyerek sadece kişilerin değil kavramların da öteki olarak temsil edilebileceğini söyler. Ona göre "adalet haklıya hakkını vermemektedir, bu yüzden ötekidir."

\subsection{Ekonomik Gücü Elinde Bulunduranlar Irkçı Șiddetin Hedefi Olabilir}

K6 Nuri Şekerci'nin bir göçmen olarak çok büyük yol kat ettiğini bu nedenle de Neonazilerin hedefinde olduğuna dikkat çekmektedir. K6'ya göre "hapishanede işletme okumuş, turizm acentesi kurmuş, tercümanlık yapmış ve özellikle de suçlulara yardım etmiştir. Bu nedenle sıradan bir göçmen değildir. Bulunduğu ülkeye oldukça uyum sağlamıştır. Almanca'yı bir Alman gibi konuşur. $O$ da pastadan pay almak, sermayeye ortak olmak isteyen ve bunu da büyük oranda gerçekleştirmiş biridir. Bu nedenle de ırkçı şiddetin hedefindedir." Diğer yandan K3 "biz Nuri'nin ne iş yaptığını nasıl bir geçmişi olduğunu biliyoruz ama Möller çiftinin meslekleri, okudukları okullar 
hakkında bir bilgiye sahip değiliz. Bence kendi yapamadıklarını bir göçmenin hatta eski bir suçlu olan göçmenin yapması onları büyük oranda rahatsız ettiği için Nuri'yi hedeflediler" şeklinde bir açıklama getirmiştir. Katılımcıların bu açıklamaları toplumda kendine saygın bir yer edinen göçmen, ırkçı düşüncelerden beslenen kesimi rahatsız etmiş ve bu durum hedefe dönüşmesinde etkili olmuştur şeklinde yorumlanabilir.

\subsection{Kahramanın Kendi Adaletini Yaratma Yolculuğu: Suçluya Dönüșen ve Yurtsuzlașan Katja}

3 katılımcı Katja'nın saldırıyı adaletten beklediği sonucu alamamasından dolayı gerçekleştirdiğini zaten ailesini kaybettikten sonra da yaşamak için bir gerekçesi kalmadığını düşünmektedir. K3'ün bu konudaki ifadeleri oldukça dikkat çekicidir: "Katja ailesini kaybetmesinin ardından banyosunda bileklerini kesip, kan kaybından ölmeyi beklediği sırada avukatının Nazilerin tutuklandıklarını söylediği mesajı duyup küvetten çıktı, bileklerini sardı. Adaletin sağlanacağına inandı o yüzden ölmekten vazgeçti. Yoksa zaten o acıyla yaşamak onun için mümkün değildi. Mahkemeden de beklediği karar çıkmadı. Çaresiz kaldı. Çaresiz insan her şeyi yapar" şeklinde yorumlamıştır. 13 katılımcı ise Katja'nın gerçekleştirdiği saldırıyı doğru bulmadıklarını ifade etmişlerdir. K2, K7, K11 ve $\mathrm{K} 15$ bu süreçte avukat gibi düşünmüş, sürecin bir üst mahkemeye taşınması gerektiğini belirtmişlerdir. K1, K13 ve K14 Katja'nın suçluya dönüştüğünü belirterek, kendi adaletini yaratma sürecini onaylamamaktadır. Benzer şekilde K4'de "eğer herkes kendi adaletini yaratacaksa hukuk neden var" diyerek Katja'nın eylemini doğru bulmamıştır. K9 ise bunu "yanlışa yanlış ile cevap vermek" şeklinde değerlendirmiştir. K5 ve K6 ise Katja'nın Edda ve Andre Möller'in yaşamına son vererek onları büyük bir vicdan azabından kurtardığını dile getirmiştir. Hatta K6 Katja intikamını onlara benzeyerek aldı, canavara dönüştü” diyerek Katja'nın adaleti sağlama biçimini doğru bulmadığını belirtmiştir. K4 ise "filmin sonunda Katja da göçmen olarak kendi ülkesinden uzakta paramparça oldu, göçmene ve suçluya dönüştü, yurtsuzlaştı" diyerek Katja'nın içinde bulunduğu durumu suçlu bir göçmene dönüşmek ve yurtsuzlaşmak olarak açıklamıştır.

\subsection{Kolluk Kuvvetlerinin Benimsedikleri Yol: Profesyonellik mi? Kendinden Olana Toz Kondurmamak mı?}

4 katılımcının saldırının gerçekleşmesinden sonraki süreçte kolluk kuvvetlerinin tutumu hakkında görüşleri son derece profesyonel oldukları noktasında birleşmektedir. K2 "profesyoneller ama bu kadar mekanik olmak zorunda mıydılar?" diyerek eleştirmiştir. Benzer şekilde K16 da "belki biz Türk olduğumuz için biraz daha empati bekledik. Bizde polis acıyı paylaşıı" diyerek bu kadar kurallara bağlı olmalarını yadırgadığını belirtmiştir. K7 ve K9 ise patlamadan sonra Katja'ya psikolojik destek vermesinin "güzel bir uygulama" olarak değerlendirmiştir. Ancak katılımcılar kolluk kuvvetlerinin soruşturmanın başlangıcında Nuri'nin suç dünyası ile geçmişteki ilişkisi sorgulanırken hiç Neonazi suç örgütlerinin göz önünde bulundurulmamasını eleştirmiştir. Hatta K12 
"kolluk kuvvetlerini oldukça yavaş bulduğunu, Neonazi çifti bulma konusunda biraz daha çabuk hareket etselerdi belki Katja bileklerini kesip intihara kalkışmayacaktı. Gerçi yakaladılar da ne oldu sonuç değişmedi” şeklinde değerlendirmiştir. Katılımcılar kolluk kuvvetlerinin benimsediği bu tutumu tarafsız olmamak şeklinde yorumlamıştır. Hatta K1 bunu "Alman milliyetçiliği, kendilerine toz kondurmadılar ilk aşamada, Doğu Avrupalı birini aradılar” şeklinde dile getirmiştir. Diğer yandan K16 komiserin Katja'yı ofisine çağırdığı sahnede "kocanız hapishaneden işletme okurken siz niye üniversiteyi yarım bıraktınız?, kocanız karanlık işlerine devam ediyor mu? gibi sorular soruyor neden bir göçmenle evlendin der gibi son derece yargılayıcı bakıyor" şeklinde bir yorum getirirken aynı komiser için K3“ komiser Katia'yı ofisine çağırdığında yargıladı ama soruşturma süresince topladığı bütün delilleri açıkça anlattı. Delilleri yok etmedi” ben bunu çok doğru ve etik buldum diyerek komiserin etik yaklaşımına dikkat çekmektedir.

\subsection{Suçun Varlığına İnanan Ama Yeterli Kanıt Bulamayan Mahkeme Heyeti}

Mahkeme heyetinin yargılama süreci içerisinde tarafı bulmadığını belirten 5 katılımcı bu davranışlarını hukuki anlamda son derece etik olarak nitelendirmektedir. 11 katılımcı ise mahkeme heyetinin doğru karar vermediğini, adaletli bir yargılama olmadığını düşünmektedir. Doğru karar vermediğini düşünen K5 "suç unsurlarının üzerindeki parmak izi önemsenmedi aslında bu delilin üzerinde durulmalıydı" diyerek mahkeme heyetinin inmalinin olduğunu düşündüğünü belirtmiştir. K3 ise "mahkeme heyetinin bu kadar az konuşmasına ve hep dışarıdan bir göz gibi izlemesine anlam veremediğini" söylerken benzer şekilde K13 de "hakim yorum hiç katmıyor, bu benim çok dikkatimi çekti, Sanırım bu onların hukuk sistemi” diyerek ait olmadığı bir toplumdaki hukuk sisteminin farklı olabileceği noktasına dikkat çekmiştir. K8'in mahkeme heyetinin süreci yönetmesi konusunda yaptığı yorum oldukça ilginçtir. K8 "mahkeme heyeti adaleti sağlayamadı. Çünkü hukuk bir adalet oyunudur. Adaleti sağlamaya gücü yetmez. Hakim kararı okurken zanlıların suçsuz olmadığına inanmıyoruz ama yeterli delilimiz yok dedi ancak oradaki herkes iyi biliyor suçlunun kim olduğunu. Eli kolu bağlı işte. Fatih Akın bunu filmin içine çok güzel yerleştirdi, kimseyi suçlamadı, buradan bir çatışma yarattı" şeklide bir okuma gerçekleşirmiştir. K8 de bu noktada yaşanan adaletsizliğin filmsel anlatı içerisinde bir çatışma unsuru yaratmak üzere bilinçli bir uygulama olduğuna dikkat çeker.

\subsection{Kimse Mükemmel Değil Herkes Sadece İnsan}

Katılımcıların tamamı masum insanların hayatına kastetmenin çok ağır bir suç olduğu ve affı olmadığı konusunda hemfikirdir. Ancak filmsel anlatı içerisinde, Nuri'nin gençliğinde uyuşturucu satması, Katja'nın ondan uyuşturucu alması ve saldırıdan sonra uyuşturucu kullanması, Danilo'nun uyuşturucu bulundurması gibi suçlara bulaşması konusunda hepimiz insanız, mükemmel değiliz yanılabilir hataya düşebiliriz şeklinde yorumlamışlardır. K16 bu durumu "kıyısından köşesinden herkesin suçun yancısı olabileceğini gösteriyor bence Fatih Akın da bunu amaçladı ve güzel bir şekilde 
gösterdi” şeklinde bir okuma gerçekleştirmiştir. Benzer şekilde K3 de filmsel anlatı içerisindeki karakterlerin oldukça gerçekçi olduğunu belirtir. K2 "hayat bizi yokuş aşağı hızla koşturuyor o yüzden hata yapmamak mümkün değil yönetmen bu duyguyu doğru yansıttı" şeklinde bu durumu değerlendirmiştir. Dolayısıyla katılımcılar Fatih Akın'ın mükemmel olmayan karakterlerinin başarılı temsillerle izleyiciyle buluştuğuna vurgu yapmaktadır.

\subsection{Perdenin Dıșından Seslenen İzleyici: Kör Alandan Adaletsizliğe İsyan}

K16 "Beraat kararı okunduktan sonra mahkeme salonunda camlı bölmenin arkasından mahkemeyi izleyen biri mahkeme heyetinin adaletine küfür etti. Başlarım böyle işe gibisinden orda yönetmen dış sesle bize yöneldi. Biz de tam olarak bunu söylemek istiyoruz aslında" diyerek mahkeme salonunda camekanın arkasında mahkemeyi takip eden izleyicinin tepkisine dikkat çeker. Benzer şekilde K8'de "haklarımızdan feragat edip şiddeti cezalandırma mekanizmasını kendimiz dışında bir devlet kurumuna devrediyoruz. Bu süreçte vicdanımızı tatmin edecek mahşeri vicdanı yaratmasını bekliyoruz. Mahkemede Danilo karşı tarafın avukatının oyunlarından tiksindiğini söylenince alkışlar yükseldi izleyiciler arasından, alkışlayanları görmedik ama alkış sesleriyle mahşeri vicdanın isyanını duyduk, bence biz de isyana katılık" diyerek mahşeri vicdana dikkat çeker. Her iki katılımcı da perdede hiçbir şekilde görünmeyen mahkemeye izleyici olarak katılanların sadece sesleriyle verdiği iki tepkiye dikkat çeker. Dolayısıyla mahkeme salonundaki izleyiciler "kameranın gördüğü alanın dışından yani kör alandan (Bonitzer, 2005:70)" seslenir. Filmde görünen, yaşayan, konuşan kişiler değildir bu izleyiciler, sadece sesleri ile perdenin dışından kameranın görmediği alandan isyan eder. Bu süreçte adalete küfür eden ve alkışlarla avukatı destekleyen mahkeme izleyicilerinin yerine filmin izleyicilerinin geçtiğini söylemek olanaklıdır.

\subsection{Peki Șimdi Adalet Var mı? Varsa Ne?}

Katılımcılara son olarak sizce adalet nedir sorusu yöneltilmiştir. 5 katılımcı adaletin varlığına inanmadıklarını belirtmişılerdir. Hatta K3 "Katja adalet olmadığı için gidip kendini patlatarak, kendi adaletini kendi sağlamaya çalıştı" diyerek düşüncesini filmin son sahnesi ile desteklemiştir. K2 "insanoğlu hep kendinden yana, burada adalet aranmaz" diyerek insanın bencilliğine vurgu yapar. K13 ise "herkes eşit şartlarda dünyaya gelmiyor, dünya adaletli bir yer değil" diyerek insanların içine doğdukları toplumsal yapının adaletsizliği ürettiğinin altını çizer. K10 ise adaletin varlığına inanmadığını "kime göre neye göre adalet" diyerek kavramın değişkenliğine vurgu yapar. K8 "mahkeme kararı hukuki ama adil değil, suçu işleyenler açık, ama somut olarak delil yetersizliği var. Burada adalet nerede?" diyerek hukuki olan ama adil olmayan mahkeme kararı ile açıklar.

K16 "aslında adalet değil de adaletsizliği daha kolay söylemek. Adaletsizlik bir insanın kocasını ve masum çocuğunu ince ince planlayarak öldürmek, hayatında ikinci şansı yakalamış bir insanı Alman değil diye öldürmek. Ama suçluların içeriye girmesi mi 
adalet bence o da değil. Adaletsizlik net ama adalet net değil. Varsa da bende tanımı yok" diyerek adaletsizliğin daha net bir biçimde açıklanabileceğini ama adaletin ve adil olmanın tanımlamanın zorluğuna olduğuna dikkat çeker.

Örneklem grubundaki 10 katılımcı ise adalete inandıklarını ve adaletin sağlanabileceğini düşündüklerini belirtmişlerdir. Adaleti; haklıyı haksızdan ayırmak, herkese eşit davranmak, suçluya gereken cezayı vermek, suçluyu suçsuzdan ayırmak, herkesin yaşama hakkını korumak, vicdanın temiz olması gibi benzer ifadelerle tanımlamışlardır. Yukarıda da görüldüğü üzere bu tanımlamalar hep hakların korunması noktasında birleşmektedir.

\section{Sonuç ve Tartıșma}

Bu çalışmada, radyo televizyon ve sinema alanında lisansüstü eğitimine devam eden 16 öğrencinin Paramparça filmini nasıl alımladıkları araştırılmıştır. Filmin gösteriminden sonra gerçekleştirilen görüşmeler üzerinden katılımcıların göçmenlik, suçluluk, adalet arayışı ve hukuk mücadelesini konu edinen bu filmi nasıl okuyup yorumladıkları bulgulanmıştır.

Örneklem grubunu oluşturan katılımcıların suç türünün tercih edip etmeme durumlarını kaçışçı hazların etkilediği görülmüştür. Suç türünü tercih etmeyen katılımcılar için adaletin tecelli etmemesi önemli bir belirleyicidir. Aksine bu türü tercih edenler ise adalet sağlandığı takdirde sisteme karşı güven tazelemektedir.

Katılımcılar filmin geneline hakim olan ve diğer suçları da tetikleyen suç türünün nefret suçu olduğu görüşünde hemfikirdir. Suçlu profili katılımcılar tarafından ideolojik olarak motive olmuş hedefe kitlenmiş kişiler olarak tanımlanmıştır. Objektif olmaya çalışan katılımcılar filmi sadece mağdur olarak gösterilen taraflar üzerinden okunmamış, saldırıyı gerçekleştirdiği düşünülen çift de anlamaya çalışmıştır. Katılımcıların büyük çoğunluğu suça karşı sessiz kalan tarafın suçu ahlaki olarak paylaştığını ifade etmiş olsalar da ırkçı şiddetin gerçek sorumlularının terör örgütleri ve adaleti sağlayamayan hukuk sistemi olduğunu düşünmektedir. Ayrıca katılımcılar soruşturma sürecinde pek çok ihtimalin göz önünde bulundurulup Neonazilerin dile getirilmemesinden rahatsızlık duymuştur. Dolayısıyla katılımcılar adaleti sağlaması gereken kurumların değerlendirmelerinde objektif ve titiz olmalarının gerekliliği şeklinde bir okuma gerçekleştirmiştir.

Katılımcıların büyük bir çoğunluğunun en dokunaklı bulduğu sahne Nuri ve Rocco'nun adli tıp raporlarının ayrıntılarıyla anlatıldığı sahnedir. Söz konusu katılımcıların her birinin çocuk sahibi olduğu göz önünde bulundurulduğunda ebeveyn olma durumlarının filmi okuma biçimine etki ettiğini söylemek olanaklıdır. Filmin en dokunaklı sahnelerinden birinin yine Katja'nın yeniden adet görmeye başladığı sahne olduğu da katılımcılar tarafından dile getirilmiştir. Katılımcılar Katja'nın biyolojik döngüsüne geri dönüşünün perdeye yansıtılma biçiminin bütün doğalığı gerçekleştirilmesini, filmsel anlatı içerisinde anlamın üretilmesi noktasında önemli bulmaktadır.

Çalışmanın bulgularına göre Alman olmayan eski bir suçlunun başarıyı yakalaması, 
kendini gerçekleştirememiş ev sahibi toplumun ırkçı şiddete eğilimli üyeleri tarafından hoş karşılanmamaktadır. Bu nedenle de kendini gerçekleştirip ekonomik gücü elinde bulunduran ve göçmen olan taraf hedef haline gelebilmektedir. Katılımcılar göçmenin cansız bedeninin yolculuğa çıkma durumundan kurtulamamasına da dikkat çekmişler, bu durumu sahip oldukları kültürel yapıdaki geleneklerle ilişkilendirerek anlamlandırmışlardır. Ayrıca katılımcıların sahip oldukları toplumsal roller özdeşlik kurmalarında etkili olurken, karakterlerin bütün olumsuz koşullara rağmen mücadeleyi bırakmaması, işin profesyonelce yapması ve karşısındaki insana karşı nazik olması ve önyargıyla yaklaşmaması da özdeşlik kurma açısından belirleyici olmuştur.

Filmde katılımcıların en çok dikkatini çeken nokta kimsenin mükemmel olmamasıdır. Bütün karakterlerin bir şekilde zayıflıklar göstermesi, insanlık durumu olarak değerlendirilmiş bu durumun yönetmen tarafından başarılı bir biçimde yansıtıldığı belirtilmiştir. Ancak masum bir insanın hayatına kastetmenin affı olmadığı konusunda da katılımcıların hemfikir olduğu görülmüştür. Ayrıca sürekli olarak karakterlerin özellikle de ebeveynlerin birbirlerini ötekileştirmesi, önyargı ile yaklaşması ve damgalayıcı davranışlar geliştirmeleri de karşı kültüre saygı duymamak birlikte yaşamayı öğrenememek olarak yorumlanmıştır.

Katılımcıların büyük çoğunluğu kadın kahramanın kendi adaletini yaratma süreci doğru bulmamışlar adaleti sağlaması gerekenin kişiler değil kurumlar olduğunu belirterek hukuk sistemini işaret etmişlerdir. Diğer yandan adaleti sağlayamayan hukuk sisteminin yarattığı mevcut koşullarda kahramanın hayatına devam etme olanağının kalmadığının, kahramanın çıktığı yolculukta göçmene ve suçluya dönüşerek yurtsuzlaştığının da altı çizilmiştir.

Araştırmanın bulguları arasında perdenin dışından kör alandan gelen isyana dikkat çekilmesi oldukça önemlidir. Kameranın görmediği alanı ne Almanlar ne de adli makamlar görmektedir. Kameranın görmediği bu alanda göçmenler bulunmaktadır. Bu nedenledir ki adalete küfür eden ve alkışlarla avukatı destekleyen izleyicilerin yerine filmin izleyicilerinin geçtiğini söylemek yanlış olmayacaktır.

Katılımcılar adalet kavramını tanımlarken zorlanmışlardır. Hatta bazı katılımcılar adaletin tanımını yapamazken, adaletin tanımını yapabilenlerin birleştiği nokta haklının haksızdan ayrılması ve haksız olanın yargılama sonunda gereken cezayı almasıdır.

Son olarak bu çalışmanın örneklem grubunu oluşturan katılımcıların filmi okuma biçimlerine hayat deneyimleri, içine doğdukları kültür, sahip oldukları toplumsal roller, aldıkları eğitim dolayısıyla sahip oldukları referans çerçeveleri ve filmsel anlatıdan beklentilerinin doğrudan etkili olduğunu söylemek yanlış olmayacaktır. 


\section{Kaynaklar}

Akbulut, H. (2014). Sinemaya Gitmek ve Seyir: Bir Sözlü Tarih Çalışması. Elektronik Mesleki Gelişim ve Araştırma Dergisi, 2, 1-16.

Allen, R. C. (1990). From Exhibition to Reception: Reflections on the Audience in Film History. Screen, 31(4), 347-356.

Balcı, E. (2014). Yeşilçam Melodramlarında Popüler Hukuk Kültürü Üzerine Bir İnceleme. (Yayınlanmamış Yüksek Lisans Tezi). Ankara: Hacettepe Üniversitesi Sosyal Bilimler Enstitüsü.

Bilgin, N. (2007). Kimlik Inşası. Ankara: Aşina Kitaplar.

Creswell, J.W. (2013). Nitel Araştırma Yöntemleri: Beş Yaklaşıma Göre Nitel Araştırma ve Araştırma Deseni. (M. Bütün ve S. B. Demir, Çev.), Ankara: Siyasal Kitabevi.

Deliormanlı, E. (2011). Fatih Akın'ın Aksanlı Sineması. S. Kırel (Der.). Sentezler (s. 273-301) içinde, İstanbul: Parşomen Yayınları.

Diken, B. ve Laustsen, C. B. (2007). Filmlerle Sosyoloji. (S. Ertekin, Çev.) İstanbul: Yayınları.

Elkins, J. R. (2007). Popular Culture Legal Films and Legal Film Critics, Loyola of Los Angeles Law Review,40, 745-792.

Erdoğan, N. (1993). Seyirci ve Sinema. Med-Campus Proje 126.

Glesne, C. (2013). Ama Bu Etik mi? Doğru Olanı Dikkate Alma. (E. Gündel, Çev.), A. Ersoy ve P. Yalçınoğlu, (Der.), Nitel Araştırmaya Giriş. (s. 223-251) Ankara: Anı Yayıncılık.

Göktuna, F. (2005). Türk Sinemasında Dışgöç Süreci (Yayınlanmamış Yüksek Lisans Tezi). Eskişehir: Anadolu Üniversitesi Sosyal Bilimler Enstitüsü.

Güler, A., Halıcıoğlu, M. B. ve Taşgın, S. (2013). Sosyal Bilimlerde Nitel Araştırma Yöntemleri. Ankara: Seçkin Yayınları.

Gürsoy, M. (2019). Göç ve Kentleşme Bağlamında Suç. İstanbul: Gece Akademi

Hake, S. ve Mennel, B. (2012). Introduction. S. Hake ve B. Mennel (Ed.). Turkish German Cinema in the New Millennium. (s. 1-19). Newyork : Berghahn Books.

Hansen, M. (1991). Babel and Babylon: Spectatorship in American silent film. Cambridge, MA: Harvard UP.

http://www.hurriyet.com.tr/yazarlar/ayse-arman/bu-filmi-yapma-dediler.erişim tarihi: 19.01.2020.

https://www.hurriyet.com.tr/avrupa/keuptaki-turk-esnafin-yarasi-hala-kapanmadi-41538110 erişim tarihi: 22.06.2020.

Jaspers, K. (2015). Suçluluk Sorunu: Almanya'nın Siyasal Sorumluluğu Üzerine. (E. Zeybekoğlu, Çev.), İstanbul: İthaki Yayınları.

Kamir, O. (2006). Framed Woman in Law and Film. London: Duke University Press.

Kanbur, A. (2005). Göçmenliğin Gölgesinde. Toplumbilim Dergisi, 18, 41-49.

Karabağ Sarı, Ç. (2012). 12 Eylül Filmlerinin Üniversiteli Gençler Tarafından Alımlanması. 
(Yayımlanmamış Doktora Tezi). Ankara Üniversitesi Sosyal Bilimler Enstitüsü, Ankara.

Karacaoğlu, E. (2014). Hukuk ve Sinema Dersi: Neden ve Nasıl?, Hukuk Kuramı, 4 (1), 1-10.

Kırel, S. (2004). Uyarlamak mı? Uyumlanmak mı?:" Tersyüz Adaptation". Galatasaray Üniversitesi Illeti-ş-im Dergisi, (1). 115-134.

Kırel, S.(2010). Kültürel çalışmalar ve Sinema. İstanbul: Kırmızı Kedi Yayınevi.

Klinger, B. (1997). Film History Terminable and Interminable: Recovering the Past in Reception Studies. Screen, 38(2), 107- 128.

Kültür, N. (2017). Aksanlı Sinema ve Fatih Akın. Maltepe Üniversitesi Iletişim Fakültesi Dergisi, 4(2), 3-17.

Lehman, P. ve Luhr, W. (2008). İzleyiciler ve Alımlama (A. Özsoy, Çev.), S. Büker ve G. Topçu (Ed.) Sinema: Tarih- Kuram- Eleştiri. (s. 171-204) içinde, İstanbul: Kırmızı Kedi Yayınları.

Miles, B. M.; Huberman, A. M. (2016). Nitel Veri Analizi. (A. Ersoy, Çev.), Ankara: Pegem Yayınları.

Monaco, J. (2002). Bir Film Nasıl Okunur. (E. Yılmaz, Çev.). İstanbul: Oğlak Yayıncılık.

Monkachi, N. (2003). Sınırdaki İki Örnekten Hareketle Göçler Sosyolojisini Yeniden Düşünmek. Toplumbilim Dergisi. 17, 57-73.

Mulvey, L. (1997). Görsel Haz ve Anlatı Sineması, (N. Abisel, Çev.), 25. Kare Dergisi 25, 211-229.

Naficy, H. (2001). An Accented Cinema: Exilic and Diasporic Filmmaking. Princeton University Press.

Noaks, L. ve Wincup, E. (2004). Criminological Reseach: Understanding Qualitative Methods. London: Sage Publishing.

Nobrega, O. S. (2015). Göçmen Tiyatro ve Kent Hakkı: Berlin'de Irksallaştıııımış Sanatçılar, Soylulaştırma ve Güvencesizleştirme. L. Körükmez ve I. Südaş (Der.). Göçler Ülkesi (s. 229-263) içinde, İstanbul: Ayrıntı Yayınları.

Özçetin, B. (2018). Kitle Iletişim Kuramları Kavramlar, Okullar, Modeller. İstanbul: İletişim Yayınları.

Punch, K.F. (2011). Sosyal Araştırmaya Giriş: Nicel ve Nitel Yaklaşımlar. (D. Bayrak, H. Aslan ve Z. Akyüz, Çev.), Ankara: Siyasal Kitabevi.

Saygılı, A. (2014). Sinema ve Hukuk Bir Tür Olarak Hukuk Filmleri. Inönü Üniversitesi Hukuk Fakültesi Dergisi, 5(1), 65-76.

Staiger, J. (2000). Perverse Spectators: The Practices of Film Reception. New York: New York University Press.

Staiger, J. (2005). Media Reception Studies. New York: New York UP.

Stam, R. (2014). Sinema Teorisine Giriş. (S. Salman ve Ç. Asatekin, Çev.). İstanbul: Ayrıntı Yayınları.

Storey, J. (2000). Popüler Kültür Çalışmaları: Kuramlar ve Metotlar. (K. Karaşahin, Çev.), İstanbul: Babil Yayınları. 
Suner, A. (2006). Hayalet ev: yeni Türk sinemasında aidiyet, kimlik ve bellek. İstanbul: Metis Yayınları.

Şimşek, H. ve Yıldırım, H. (2011). Sosyal Bilimlerde Nitel Araştırma Yöntemleri. Ankara: Seçkin Yayıncılık.

Tauscher, S. ve Bezci, B. (2016). Son Dönem Almanya'sında Yabancı Hakları Tartışmaları. Uluslararası Politik Araştırmalar Dergisi, 7 (3), 74-89.

Türkoğlu, M. (2002). Türk Sinemasında Dışgöçü Konu Alan Filmlerde Kültürel Kimlik Bağlamında Ötekinin Temsili.(Yayınlanmamış Yüksek Lisans Tezi). Ankara: Gazi Üniversitesi Sosyal Bilimler Enstitüsü.

Ulusay, N. (2008). Melez Imgeler Sinema ve Ulusötesi Yaklaşımlar. Ankara: Dost Kitabevi.

Ulusay, N. (2012). Göçmen: Duvara Karşı Bir Beden. U. T. Aslan (Der.). Bir Kapıdan Gireceksin. (s.119-133)içinde, İstanbul: Metis Yayınları.

Unat Abadan, N. (2006). Bitmeyen Göç. İstanbul: İstanbul Bilgi Üniversitesi

Ünver, O. C. (2012). Dönerci Cinayetleri: Son Gelişmeler Işığında Almanya'da Türklere Yönelik Irkçı Şiddetin Siyasal Sonuçları. Ufuk Üniversitesi Sosyal Bilimler Enstitüsü Dergisi, 2 (2), 92-106.

Ünver, O. C. (2014). Neoliberalizm ve Almanya'da Güçlenen Yeni Irkçılığın Hedefindeki Türkler. Idealkent, 5(14), 124-152.

Yaren, Ö. (2008). Altyazılı Rüyalar Avrupa Göçmen Sineması. Ankara: De ki Yayınları.

Yılmaz Elmaz, F. (2013). Avrupa'da Türkler. Türk Cumhuriyetleri ve Toplulukları Yıllığı, 535-553.

\section{Extended Summary}

This is a reception study on a movie named "In the Fade (Aus dem Nichts)" of the director Fatih Akin, which was released in 2017. Although using the themes of accented cinema, the movie turns those themes round as the narrative proceeds, presenting strong representations crime, guilt, legal struggle and the seek for justice. The gross sample used in this study compose of 16 participants all of whom are postgraduate students majoring in the field of radio-television and cinema.

The movies of the crime genre present a pleasure of escape that makes this genre preferable. What is determinant for the participants who do not prefer the crime movies is thought that the justice is not served in this genre. On the contrary, for those who prefer crime genre, when the justice is secured in the movie, it restores the trust in the system.

The participants agree that the one crime that dominates the movie and triggers all other crimes in the story is a hate crime. The participants define the criminals as people who are ideologically motivated and target-oriented.

The findings of the study suggest that the self-realization of a non-German man with a history of crime is not looked upon with favor by the members with racist violent 
tendencies of the hosting society which failed to realize itself. Therefore, the party of the migrants who self-realize and obtain economic power becomes a target. The participants also point out how the conditions forced the body of a migrant to embark on the journey, interpreting this situation in relation to the traditions within their own cultural structure.

In the movie, the participants especially noted that no one was perfect. As all characters show weakness one way or another, the participants consider this as a part of being human, and state that this situation was successfully reflected on the screen by the director. However, all the participants agree that there is no forgiveness for making an attempt on an innocent's life.

Most of the participants do not approve the self-administered justice, and signify the concept of legal system, stating that not individuals but institutions should secure the justice. The participants also underline that the protagonist transforms into a migrant and a criminal, and becomes stateless.

Another noticeable point among the findings of the research is the attention drawn to the revolt coming from the blind spot outside the screen. What the camera cannot see is also invisible to Germans or legal authorities. Therefore, it is not wrong to say that the viewers who curse the justice and support the attorney with an applause are replaced by the audience of the movie.

The participants had a hard time defining the concept of justice. While some of the participants could not make a definition of justice, who could make a definition unite in the idea that justice is the distinguishing of right from wrong and giving the wrong a proper punishment after a proper trial.

In conclusion, it will not be wrong to say that the way the participants of the sample group read a movie is affected by their experiences, the culture in which they born, the social roles they claim, the social references they obtain as a result of the education they get, and their expectations from a movie. 